Jurnal ASPIKOM, Vol. 6, No. 2, July 2021, pp. 345-359

P-ISSN: 2087-0442, E-ISSN: 2548-8309

DOI: http://dx.doi.org/10.24329/aspikom.v6i2.936

\title{
How Novice Entrepreneurs Learn About Digital Marketing Communication Strategies?
}

\section{Bagaimana Wirausaha Pemula Belajar Tentang Strategi Komunikasi Pemasaran Digital?}

\author{
Miftahul Rozaq*, Sri Hastjarjo, Yulius Slamet \\ Universitas Sebelas Maret. Jl. Ir. Sutami 36A Surakarta, Central Java, Indonesia \\ *Corresponding author, e-mail: miftahulrozaq19@gmail.com
}

\begin{abstract}
This study aims to investigate the process of learning digital communication strategies by novice entrepreneurs who have limited knowledge, information, and access to formal training by learning through observations on social media to develop their business. This study used a qualitative approach with a case study design of six start-up entrepreneurs from micro, small and medium enterprises in Surakarta, Indonesia. In-depth interviews were conducted with six start-up entrepreneurs to study the social media situation in modeling and the meaning of the social media communication strategy being modeled. The results showed that role modeling occurred based on the needs of novice entrepreneurs to learn social media communication strategies. Also, the correct meaning of social media communication strategies is a determining factor that leads to the self-efficacy of novice entrepreneurs to make similar imitation decisions, develop observed strategies, or create new versions of strategies.
\end{abstract}

Keywords: Communication strategies; Learning through modeling; Novice entrepreneurial; Receptions; Social media

\begin{abstract}
Abstrak
Penelitian ini bertujuan untuk menyelidiki proses belajar strategi komunikasi digital oleh wirausaha pemula yang memiliki keterbatasan pengetahuan, informasi, dan akses pelatihan secara formal dengan belajar melalui pengamatan di media sosial dalam upaya mengembangkan usahanya. Penelitian ini menggunakan pendekatan kualitatif dengan desain studi kasus terhadap enam wirausha pemula dari usaha mikro, kecil dan menengah di Kota Surakarta, Indonesia. Wawancara mendalam dilakukan kepada enam wirausaha pemula untuk mengkaji situasi media sosial dalam melakukan pemodelan, dan pemaknaan strategi komunikasi media sosial yang dimodelkan. Hasil penelitian menunjukkan pemodelan peran terjadi didasarkan pada kebutuhan wirausaha pemula pada tugas strategi komunikasi media sosial yang dipelajari. Selain itu, pemaknaan strategi komunikasi media sosial secara tepat menjadi faktor penentu yang mengarah pada keyakinan diri wirausaha pemula untuk keputusan melakukan imitasi serupa, mengembangkan strategi yang telah diamati atau membuat strategi versi baru.
\end{abstract}

Kata Kunci: Belajar melalui pemodelan; Sosial media; Strategi komunikasi; Resepsi; Wirausaha pemula 


\section{Introduction}

Novice entrepreneurs, including Micro, Small, and Medium Enterprises (MSMEs), have experienced an increase every year. However, regarding its contribution to the formation of gross domestic product (GDP), the role of MSMEs is always more minor in job creation (Tambunan, 2019). Of the total $99 \%$ employment, they only contributed around $61.41 \%$ of GDP in 2017. This is due to factors including their limited access to advanced technology, capital, and human resources, resulting in their productivity being much lower than that of big companies.

In this era of technology, in general, MSMEs use technology, especially social media, as a tool to expand the marketing segmentation of the products they produce. The use of social media for novice entrepreneurs generated various benefits, especially in developing countries, as a marketing tool for entrepreneurs to simplify various obstacles in the communication process, including access to customers, suppliers, partners, and other necessary resources (Park, Sung, \& Im, 2017; Turan \& Kara, 2018) at a relatively low cost (Basri \& Siam, 2017).

Likewise, with the existence of MSMEs in the city of Surakarta, Indonesia, the current era of technology requires MSMEs to continue to adapt by utilizing various existing social media platforms. However, most MSMEs in the city of Surakarta, especially novice entrepreneurs, are not ready to face the digitalization era due to various obstacles, such as weak business management and lack of promotional media in product marketing. The results of interviews in the field show that various obstacles faced by novice entrepreneurs in the city of Surakarta include (1) limited knowledge about how to maximize communication technology for their business purposes, (2) limited human resources, (3) limited budgetary capital, and (4) entrepreneurs do not get access to training or coaching from the relevant agencies/institutions, especially those related to the use of communication technology.

Due to the limitations of various resources, including knowledge, information, and access to formal training (Tambunan, 2019), the most common way to gain new knowledge and skills for novice entrepreneurs is to engage in experiments or imitate other business strategies (Bosma, Hessels, Schutjens, Praag, \& Verheul, 2012; Zozimo, Jack, \& Hamilton, 2017). Novice entrepreneurs learn by observing informally and then adopting social behavior, namely learning by example rather than relying on their limited experience as new business players, especially in digital platforms. In using social media for start-ups, the most important thing to do is build a communication strategy to improve business reputation and product identity (Bresciani \& Eppler, 2010; Park et al., 2017; Petkova \& Rindova, 2008).

The phenomenon of social learning in entrepreneurship in the current era of communication technology development is very interesting to study, given that the literature related to social learning in entrepreneurship is slow in developing a framework for understanding the complexities of social learning in entrepreneurship (Wang \& Chugh, 2014), especially in the digital media environment. which is growing nowadays. So, it is interesting to study how this novice entrepreneur in the city of Surakarta, who has limited knowledge, budget, or does not get access to training from related agencies/institutions, can adapt to the increasingly competitive digital era today by learning about social strategies related to communication in the social media environment as an effort to develop their business.

This study seeks to fill the gap in the previous literature on social learning in entrepreneurship, which continues to experience developments in the current era of 
communication technology. Previous research had shown how entrepreneurs learn through other people (Bosma et al., 2012) specifically from role models in certain social contexts (Zozimo et al., 2017), for example, through the role models of parents in the family environment (Hoffmann, Junge, \& Malchow-Møller, 2015), guest speaker (Fiet, 2001), colleagues, and university environment (Kacperczyk, 2013). However, how the social learning process of entrepreneurship in the social media environment, especially regarding digital communication strategies, has not been discussed.

Expanding on previous research, we try to describe the process of learning digital communication strategies by novice entrepreneurs in the social media environment. The description include their role model (for example, other businesses that are considered successful, celebrities, youtubers, content creators, etc.), relevance to certain social media contexts (eg. , Instagram, YouTube, Facebook, websites, etc.), and what they learn with digital communication strategies for beginner entrepreneurs, for example, how to share information, how to promote and mobilize, how to listen to social, customer service and dialogue, how to build a leadership mindset, co-branding, how to take advantage of the support of influencers (Chen, Ji, \& Men, 2017; Men \& Tsai, 2012; Saxton \& Waters, 2014).

Social cognitive theory (Bandura, 1977, 1986) is used to examine the learning process of beginner entrepreneurs through observing role models in social media. Bandura (1977) believes that humans are active information processors who know and weigh the advantages and disadvantages of learned behavior. The ability to assess, interpret and apply (external) knowledge (i.e. the influence of the observed model) requires a certain level of knowledge and skills (Bosma et al., 2012). Success in carrying out the learning process (modeling) through observations on social media is influenced by environmental, individual, and behavioral factors (Bandura, 2012). To find out how novice entrepreneurs receive messages about digital communication strategies learned from external factors, namely social media, this study was analyzed using the theory of message reception by Stuart Hall (1973).

To be able to examine the complex phenomenon of social learning in entrepreneurship in the social media environment related to the digital communication strategy tasks studied, we offer an in-depth approach using the case study method of six budding entrepreneurs in the city of Surakarta in the process of learning social media communication strategies. Due to limited knowledge, skills, budget, and lack of access to training from relevant agencies/institutions, in the current digitalization era, novice entrepreneurs in Surakarta choose to learn informally by observing various communication strategies on social media. Finally, this study examines the learning process of digital communication strategies by novice entrepreneurs through modeling on social media to develop their business.

This research was conducted in the city of Surakarta, Central Java province. In Indonesia, the majority of MSMEs are located on the island of Java, the most populous island and also the center of Indonesia's economy and financial activities (BPS, 2017a). According to BPS data in 2017, Central Java occupies the first position with the largest number of micro MSMEs in Indonesia, reaching 857,981 business units. Small businesses, meanwhile, occupy the second position after East Java with 54,440 business units. The city of Surakarta is one of the cities that is oriented towards the trade and MSME sector. Based on BPS data in BPS (2017b) shows the number and percentage of small and micro enterprises in Surakarta are $19.27 \%$ higher than, for example, Semarang $15.77 \%$, Kedu 16.63\%, Starch $12.85 \%$. Meanwhile, based on data from the 
Surakarta City Cooperative and SME Office, for novice entrepreneurs themselves, in 2018 there were 60 people, in 2019 there were 294 people, and in mid-2020 there were 290 who were still being evaluated. That is the reason this research was conducted in Surakarta because the potential for beginner MSMEs has increased from year to year.

\section{Method}

This study uses the interpretivism paradigm with a qualitative approach. The method used is a descriptive case study, according to Yin (2018), based on descriptive research to provide a narrative description of a social phenomenon under study. This research was conducted on beginner entrepreneurs in the city of Surakarta from August 2020 to February 2021.

The sampling technique was carried out purposively by the problems and objectives of the research conducted. The informants' criteria include, (1) novice entrepreneurs who are running businesses that have the potential to be developed in the first three years of running a business according to the provisions of the KemenkopUKM R1 in 2019, (2) are beginner SMEs according to the categories by KemenkopUKM 2019, (3) novice entrepreneurs who use one of the social media platforms as a medium of business communication, (4) business owners who are social media managers.

While the sampling technique used the maximum variation sample by taking samples from Micro, Small, and Medium Enterprises that were beginners by determining the category of MSMEs according to Law No. 20 of 2008 concerning the classification of MSMEs and an alternative number of workers, annual income adopted by BPS. Respondent information can be seen in Table 1 .

Table 1. Respondent Information

\begin{tabular}{|c|c|c|c|c|c|}
\hline Informant & $\begin{array}{l}\text { Type of } \\
\text { business }\end{array}$ & $\begin{array}{c}\text { Duration } \\
\text { of } \\
\text { Business } \\
\text { Founded }\end{array}$ & $\begin{array}{c}\text { The } \\
\text { Number of } \\
\text { workers }\end{array}$ & $\begin{array}{l}\text { Business } \\
\text { Category }\end{array}$ & $\begin{array}{l}\text { Social Media } \\
\text { Used }\end{array}$ \\
\hline Andrika & $\begin{array}{l}\text { Women' } \\
\text { s } \\
\text { Clothing } \\
\text { and } \\
\text { Accesso } \\
\text { ries }\end{array}$ & $\begin{array}{l}\text { Three } \\
\text { years }\end{array}$ & 26 People & $\begin{array}{l}\text { Medium } \\
\text { Enterprises }\end{array}$ & $\begin{array}{l}\text { Instagram : } \\
\text { @ mikastore_solo, } \\
\text { @ mikastore_uns, } \\
\text { @ mikastore_sepat } \\
\text { utas. } \\
\text { Whatsapp }\end{array}$ \\
\hline Aditya & $\begin{array}{l}\text { Clothing } \\
\text { and T- } \\
\text { Shirt } \\
\text { Custom } \\
\text { Services }\end{array}$ & Two years & 20 People & $\begin{array}{c}\text { Medium } \\
\text { Enterprises }\end{array}$ & $\begin{array}{l}\text { Instagram: } \\
@ \text { maustore.id } \\
@ \text { maucustom.id } \\
\text { Whatsapp }\end{array}$ \\
\hline Fajrin & $\begin{array}{l}\text { Food } \\
\text { and } \\
\text { Drink }\end{array}$ & $\begin{array}{l}\text { Three } \\
\text { years }\end{array}$ & 20 People & $\begin{array}{c}\text { Small } \\
\text { business }\end{array}$ & $\begin{array}{l}\text { Instagram: } \\
\text { @ kedaisharing } \\
\text { Facebook } \\
\text { Fanspage }\end{array}$ \\
\hline Aldi & $\begin{array}{l}\text { Coffee } \\
\text { shop }\end{array}$ & $\begin{array}{c}\text { Six } \\
\text { months }\end{array}$ & 6 People & $\begin{array}{c}\text { Small } \\
\text { business }\end{array}$ & $\begin{array}{l}\text { Instagram: } \\
\text { @ uptown.coffenea } \\
\text { tery }\end{array}$ \\
\hline
\end{tabular}




\begin{tabular}{|c|c|c|c|c|c|}
\hline Wahyu & $\begin{array}{l}\text { Package } \\
\text { d } \\
\text { Beverag } \\
\text { es }\end{array}$ & $\begin{array}{l}\text { Eight } \\
\text { months }\end{array}$ & 3 People & $\begin{array}{c}\text { Micro } \\
\text { business }\end{array}$ & $\begin{array}{l}\text { Instagram: } \\
\text { @ littlemo.id }\end{array}$ \\
\hline Anny & Food & $\begin{array}{l}\text { Eight } \\
\text { months }\end{array}$ & 2 People & $\begin{array}{c}\text { Micro } \\
\text { business }\end{array}$ & $\begin{array}{l}\text { Instagram : } \\
\text { @ pempekzakwan_ } \\
\text { solo } \\
\text { Facebook : } \\
\text { Pempek Zakwan } \\
\text { Whatsapp }\end{array}$ \\
\hline
\end{tabular}

Data were collected using in-depth interviews conducted openly to novice entrepreneurs who were selected as informants to serve as primary data sources. Meanwhile, secondary data is in the form of data on the number of annual sales and the number of workers obtained from beginner entrepreneurs. Also, secondary data was taken from the Central Statistics Agency (BPS)'s data on the potential of MSMEs, MSME data in the City of Surakarta obtained from the Surakarta City Cooperative and SME Office. Data on beginner entrepreneurs in Surakarta City are obtained from the Cooperative and UMKM Offices in Surakarta City, according to Law No. 20 of 2008 on MSMEs.

Two types of informants were selected to obtain valid data. First, the business owners, as key informants who understand in general and conceptually how the business works and learns related to its business communication strategy. The second main informant was social media managers who technically know how content creation and social media communication strategies are implemented.

Data triangulation and method triangulation were chosen to obtain convincing data validity. Data analysis was used from Matthew B. Miles, A. Michael Huberman (2014) after the data collected was performed data reduction, data presentation, and concluding. Then, triangulation was carried out to check the validity of the research data.

\section{Results and Discussion}

\section{The Learning Process of Digital Marketing Communication Strategies By Novice Entrepreneurs on Social Media}

Previous literature has discussed the importance of social context in observing role models and how it affects entrepreneurial learning. This study examines three contexts of social situations in the learning process through observation and various social media settings in the learning process of social media communication strategies by novice entrepreneurs. (Bandura, 2012) describes three main factors that influence success in the learning process (modeling) which is carried out through observations in the mass media, namely environmental factors, individual behavioral factors.

Expanding on the results of Zozimo, Jack, \& Hamilton (2017) research, which examines the entrepreneurial learning process in certain social situations, we describe how novice entrepreneurs learn about digital marketing communication strategies. For example, who are the role models for budding entrepreneurs in social media (personal factors), what social media they used to observe their role models (environmental factors), and what budding entrepreneurs learned about social media communication strategies (behavioral factors). The results of the study are as follows: 


\section{The Role Model of Novice Entrepreneurs in Social Media (Personal Factors)}

The results showed that novice entrepreneurs, both Micro, Small, and Medium Enterprises, did not precisely follow one of the role models to be used as a role model. On social media, they observe several/many role models for reference in their learning process depending on the studied material. Fajrin, a small business actor, said, "If we observe, it is certain, this is to add references. We will see in other business Instagram feeds or stories that I think can be applied here.

In addition, for example, Aditya revealed that he observed several references while learning about promotion and mobilization strategies. Aditya, a small business actor, revealed:

In doing promotions, we observe several other entrepreneurs. They can be said as references, especially on how to do promotions on social media. For example, they intensively create content that offers low prices with good material. In addition, they also offer a speedy service that can process purchases to please their customers (Aditya).

Novice entrepreneurs also revealed that they prefer to develop strategies that are observed on social media and adapt to their own identities. Aldi, as a small business owner, said, "We tend to observe social media strategies from other businesses and then we develop them ourselves according to our needs". In addition, novice entrepreneurs also have an interest in role models on social media that inspire them to create and learn content on social media. Andrika, as a medium-sized business owner, said, "the hijab celebgrams who inspire online shops are our role models on social media".

Meanwhile, Anny, a micro-business actor, explained that she used her business partners as role models on social media. She observed role models when conducting collaboration strategies on social media. Anni revealed, "To learn how to create content, I learn from my business partners when we collaborate to promote products on each other's social media. This also increases our knowledge for the future". In addition, in carrying out a strategy to utilize the support of third-party influencers, Wahyu, a micro-business actor, revealed that he learned from observing other businesses, "after we observed other business trends we decided to do an endorsement to the@diskonsolo Instagram account”(Wahyu).

\section{Digital Marketing Communication Strategies Learned by Novice Entrepreneurs (Behavioral Factors)}

The results showed that the digital marketing communication strategies studied by novice entrepreneurs match those identified by Chen et al. (2017). In fact, information dissemination and sharing strategies, promotion and mobilization strategies, social listening strategies, customer service, and dialogue, building a professional image, cobranding, take advantage of support from third-party influencers.

First, in learning about information dissemination and sharing strategies, Fajrin, a small business actor, said, "If we observe it, it is certain. For example, we observe things that we think are important, such as updating information about changes in operating hours" (Fajrin). In addition, Aldi, a small business actor, said that he learned from several other businesses regarding the strategy of informing new products, promos, and discounts, "we tend to observe social media strategies from other businesses. For example, to inform customers via Instagram about operating hours, new 
products, promotions, discounts, etc. (Aldi).

Then in learning about promotion and mobilization strategies. Content strategies that focus on promotion are commonly used by start-up entrepreneurs, especially those who offer products and services that directly target consumers. Aditya, a medium-sized business actor, said, "In carrying out promotions, we observe several other businesses. For example, they intensively create content that offers low prices with good material. In addition, they also offer a speedy service that can process purchases to please their customers" (Aditya). In addition, Aldi, as a novice entrepreneur, revealed that he learned to inform customers when holding business opening events. Aldi revealed:

We pay more attention to some other entrepreneurs. For example, in a promotional announcement, we inform you of the event that we held on Instagram yesterday. We distributed a Lunar red package for a 100 thousand transaction. We gave an envelope containing a voucher (Aldi).

Furthermore, the results also show that entrepreneurs learn about customer listening, customer service, and dialogue strategies to encourage customer participation. By having two-way conversations and communication with customers, it is believed to be able to resolve customer problems and complaints more quickly. Andrika as a medium-sized entrepreneur, revealed:

We are inspired by hijab celebrities such as how to maximize customer communication by replying to customer comments on Instagram as much as possible when asking about the product they are looking for. We also mediate some questions and customer complaints via direct messages and WhatsApp. This has proven to be effective for maintaining relationships and solving customer problems (Andrika).

In addition, Fajrin, a small business actor, revealed that he learned from other businesses to maximize search engines to make it easier for customers to find their presence on the internet. Fajrin said, "what do we learn from other coffeeshops" efforts to build relationships with customers. For example, how they optimize search engine optimization (SEO), which is in sync with Google Map, where customers can provide feedback about ratings and comments (Fajrin).

The interview results also show that novice entrepreneurs are co-branding on social media through collaboration with other more extensive social media accounts, other businesses, and their business partners. As stated by Anny, a micro-business actor, "we also work with our partners whose businesses are quite stable. We collaborate to promote products on each other's social media to increase wider exposure to customers. This also increases our knowledge for the future. (Annie). In addition, in carrying out the co-branding collaboration strategy, Aditya, a medium-sized business actor, revealed that he endorsed several larger social media accounts. Aditya says:

Since we are currently holding a promotion, we tried to do some searching on the web to learn how to expand the reach of the promotion effectively. Finally, we decided to collaborate with the Instagram account @agendasolo, @diskonsolo, which is proven to provide exposure for wider delivery (Aditya).

Entrepreneurs also mention that they learn by observing how to leverage thirdparty influencers or endorsements. Fajrin, a small business actor, revealed, "We observed other entrepreneurs doing endorsements on social media, then we tried to do 
so by endorsement to the @kulinersolo account, and paying promotions to other accounts whose results proved effective (Fajrin). In addition, Wahyu, a micro-business actor, also revealed that he endorsed larger social media accounts, "When we first launched an outlet, we previously mapped out what we had to do, especially for social media strategy. After we observed other business trends, we decided to do an endorsement to the Instagram account @diskonsolo" (Wahyu).

\section{Social Media Situation Used (Environmental Factors)}

Social media used by budding entrepreneurs as a tool for digital marketing communication strategies can help entrepreneurs to expand their reach in developing their business. Beginner entrepreneurs who start businesses with limited knowledge and resources are heavily influenced by social media to find out trends and opportunities. In the use of social media, novice entrepreneurs use social media as an internal tool for promotion. Andrika, as a medium-sized business actor, said, "We use social media for sales promotion through Instagram". In addition, Fajrin revealed that Instagram as a visual-based social media is very interesting to create content with creative strategies:

"Because I think it is better for visual content, I watch other business content on Instagram more and then we modify it ourselves into short videos that we use on Instagram" (Fajrin).

In addition, Wahyu, a small business actor, revealed that he focuses on Instagram social media because, according to him, it is widely used by all groups from young people to the elderly, "Yes, we are currently focusing on Instagram, because we see the trend of social media users being widely used by all groups from the young to the old." In line with this, Aditya, a medium-sized business actor, revealed that the use of Instagram social media has more impact on his business, "for social media we use Instagram because it is faster on Instagram". Furthermore, Anni, a micro-business actor, argues that according to what she observes from her business partners, Instagram is very effective for expanding marketing, "its social media for Instagram promos, I think when collaborating with our partners, I observe what our business partners do in maximizing social media for promotion and when informing the event that is being held is very effective in attracting the audience.

Then Aldi revealed that learning by observing on Instagram is easier because it has features that can support him in developing strategies in content creation. Aldi said, "besides having trends that are in great demand by various circles, Instagram can support our learning process because the content we observe if it is appropriate is easy to save, enlarge and be more detailed".

Tabel 2. The Learning Process of Digital Marketing Communication Strategies Through Role Models by Novice Entrepreneurs in Social Media

\begin{tabular}{llll}
\hline \multicolumn{1}{c}{ Informant } & \multicolumn{1}{c}{$\begin{array}{c}\text { Learned Communication } \\
\text { Strategies }\end{array}$} & Role Model & $\begin{array}{c}\text { Social Media } \\
\text { Situation }\end{array}$ \\
\hline Fajrin & $\begin{array}{l}\text { Strategy for disseminating and } \\
\text { sharing information with } \\
\text { customers }\end{array}$ & Another venture & Instagram \\
\cline { 2 - 4 } Aldi & $\begin{array}{l}\text { Another venture } \\
\text { Promotion and mobilization }\end{array}$ & Instagram \\
\hline Aditya & strategies & Another venture & Instagram \\
\hline Aldi & $\begin{array}{l}\text { Listening to customers, customer } \\
\text { Andrika }\end{array}$ & Celebgram & Instagram \\
\cline { 3 - 4 } Fajrin & service, and dialogue & Another venture & Instagram \\
\hline
\end{tabular}




\begin{tabular}{llll}
\hline Anny & Co-branding strategy & Business partner & $\begin{array}{c}\text { Instagram } \\
\text { Aditya }\end{array}$ \\
\cline { 3 - 4 } & Creator content & $\begin{array}{l}\text { Website, } \\
\text { Youtube }\end{array}$ \\
\hline Fajrin & $\begin{array}{l}\text { Strategies to leverage influencer } \\
\text { support }\end{array}$ & Another venture & Instagram \\
\cline { 3 - 4 } Wahyu & Another venture & Instagram \\
\hline
\end{tabular}

The results of the study indicate that novice entrepreneurs do not follow a specific role model to be a role model. On social media, budding entrepreneurs tend to observe many role models such as other similar businesses that are considered successful, celebrities, other content creators are kept for reference, and they study them again for adoption when needed. They tend to save what they have observed and learned from observations on social media and combine, modify, and develop what they have observed according to their own identity and branding goals.

The social media strategies studied by novice entrepreneurs on social media or (behavioral factors) observed were mentioned by novice entrepreneurs, most of which have been identified by Chen et al (2017), among others, information dissemination and mobilization strategies to create content about news events held, new product launches, and new partnerships with other businesses. Then promotion and mobilization strategies to offer products and services that directly target consumers. Furthermore, the strategies of listening to customers, customer service, and dialogue to have two-way conversations and communication with customers are also mentioned by entrepreneurs. In addition, the co-branding strategy is also learned by budding entrepreneurs by collaborating with other larger social media accounts, other businesses, and their business partners. Lastly, strategies for leveraging the support of third-party influencers are also studied by budding entrepreneurs.

The social media environment used for the learning process of digital communication strategies through observations on social media or (environmental factors) shows that most entrepreneurs learn through observations on Instagram. Accordingly, the entrepreneurs use social media to know what they currently need, the trend that everyone uses, and that it is easy to learn. In addition, in studying certain social media communication strategies, novice entrepreneurs also observe several websites and YouTube videos as a reference to learn specific communication strategies needed.

\section{Receptions of Novice Entrepreneurs on Communication Strategies Modeled in Social Media}

In addition to the three contexts of social media situations that influence each other between personal, behavioral, and environmental factors proposed by Bandura (1986), in supporting the communication strategy learning process that has been modeled, the acceptance of novice entrepreneurs on the modeled media communication strategy tasks can be interpreted appropriately by novice entrepreneurs will be very supportive of modeling. Stuart Hall's acceptance analysis of the encoding-decoding model used on request. The results of Shaw's research (2017) using acceptance analysis by Stuart Hall (1973) states that there are three levels of audiences in receiving messages through digital media for interactive learning processes, including dominant hegemonic position, negotiation position, and opposition position.

\section{Dominant Hegemonic Position}

In this order, novice entrepreneurs interpret the same as social media communication strategies which are modeled according to the intended meaning and are 
offered media texts that have been observed on social media. Novice entrepreneurs who have the same understanding will not limit messages, views and immediately accept them. The results of interviews with novice entrepreneurs in this situation show, first in the process of learning social media strategies on how to share information, novice entrepreneurs reveal:

We have observed and learned from other Coffeeshop social media accounts that they can always update information, such as notifying customers about a promo program being run. They also inform customers via social media about changes in operational hours. We think this is very useful, and we will apply it to our communication strategy to try to be able to constantly update the latest information on our social media (Fajrin).

In this position, novice entrepreneurs also reveal that what they observe from accounts on Instagram in carrying out promotions is very interesting and they have practiced it. As said by Wahyu, a micro-business actor:

I thinkwhatwe have observed from accounts like@kulinersolo, @jajansolo is very interesting, and we have put it into practice. For example, in doing promo programs like yesterday during Chinese New Year. The moments of this big day and the holiday period are very effective for promoting (Wahyu).

The results of the interviews also showed that what they did from their observations on social media such as co-branding strategies through collaboration with other social media accounts that were more like the social media accounts of other entrepreneurs or business partners was very useful for gaining greater exposure.

In our opinion, other businesses' social media communication strategies on social media that are carried out in collaboration together to promote products on social media are very good. This can increase a wider exposure to customers (Anny).

In other words, in the dominant way of meaning, novice entrepreneurs assume that if the observed strategy will impact their business development, the self-efficacy of novice entrepreneurs to imitate a similar communication strategy according to what has been observed and observed.

\section{Negotiated Position}

This position is a combination position. On the one hand, novice entrepreneurs can catch the dominant code in the text, but some reject it and choose which is suitable or not in certain cases. They match the needs and goals of their business strategy and develop according to the knowledge they have, first, about the strategy of sharing information with customers.

Novice entrepreneurs revealed that in their negotiating position, they did not simply adopt what had been observed on social media in learning about promotion and mobilization. Novice entrepreneurs mix their existing knowledge to develop promotion and mobilization strategies further:

In learning how to promote from what we have observed on several other business social media accounts, we do not make them one benchmark. The most basic, in our opinion, is the style. So the concept is that we have to adapt to our character. For example, for now, we are prioritizing products. (Aldi). 
Furthermore, in this position, novice entrepreneurs also mentioned that learning about strategies for managing relationships with customers on social media by listening to customers, customer service, and dialogue to carry out two-way communication is important. Also, it will be maximized if one can maximize all social media, not only focus on Instagram. In this position, Fajrin, a small business actor, revealed:

We also try to apply our learning results from several other entrepreneurs we observe. We answer that they are always active in providing feedback in the Instagram review column, this is very important to give a positive impression to customers and build relationships. However, in our opinion, this should also be maximized only on Instagram social media. For example, we also optimize search engine optimization (SEO), which is synchronized with Google Map, where we can also provide feedback on customer comments and see the ratings given by customers (Fajrin).

Lastly, novice entrepreneurs in learning about how to take advantage of thirdparty support through influencers from what they observe on social media in their negotiating position revealed that utilizing influencer support is very useful to assist in sharing content on social media. However, this must be done selectively to choose influencers that fit the target audience so that they can have an impact on the business as a whole. In this position the novice entrepreneur reveals:

We observe on social media, how other Food \& Beverage $(F \& B)$ industry businesses have endorsed and paid for promotion to Instagram accounts such as @kulinersolo, @diskonsolo. We think this strategy is important and effective to adopt to help share content on social media. But in our opinion, in carrying out this strategy, we must selectively choose influences that can represent our products. In this growing digital era, we think consumers are getting smarter. So we also have to be smart in choosing influences that are in line with our targets to get an overall business impact (Fajrin).

In other words, in the process of learning social media communication strategies, especially in the negotiation acceptance position, novice entrepreneurs have confidence in the observed strategies. The study showed that these novice entrepreneurs have obtained benefits and have confidence in their knowledge and abilities to be in a position. In this case, novice entrepreneurs will model communication strategies according to what is observed to be effective. However, in the setting up, novice entrepreneurs will also develop and adapt according to their knowledge of social media communication strategies to get innovations.

\section{Oppositional Position}

Opposition acceptance position occurs when novice entrepreneurs interpret social media communication strategies that are modeled differently from what their models display on social media. This is because novice entrepreneurs have different views which are marked by mismatch with the observed communication strategy. For example, when learning about strategies for managing relationships with customers through listening to customers, customer service, and dialogue, Aldi, a small-sized business actor, revealed:

According to what I have observed from other businesses in social media, the relationship management strategy used does not identify specific market segments. We think that managing relationships is very important to identify 
specific market segments who are most likely to buy our products. We can do this by dissecting the consumer's profile, the area, their behavior to the problem at hand. For this, we are pursuing a strategy of managing relationships by approaching our targets directly, through direct messages one by one (Aldi).

In addition, in conducting learning about promotion and mobilization strategies on social media in the entrepreneurial environment, beginners also disclose that carrying out promotional strategies on social media was done ordinarily. According to the interviews, entrepreneurs said that in an era of increasingly competitive technological developments, promotion and mobilization strategies must be carried out in a way that is not ordinary. Products must be extraordinary and must determine the USP (unique selling proposition), which has a selling value. As the proposal by Aditya, medium business actors:

In learning how to carry out a promotional strategy on social media, we looked at several other efforts as references. But in our opinion, the promotion strategy that we observed from several other businesses is the old-fashioned promotion strategy. In our opinion, in an era of increasingly competitive social media development, it is necessary to carry out an anti-stream promotion strategy. For example, we do promotions on social media not only offering plain shirts at low prices and good quality. But we also offer custom t-shirt services by using unique words for t-shirt designs. Buyers can also order $t$-shirts with unique unit inscriptions with one day processing time. They can also pay once the order is completed and is paid on the spot. We think this can provide a positive experience to consumers and will automatically be recommended to friends or family (Aditya).

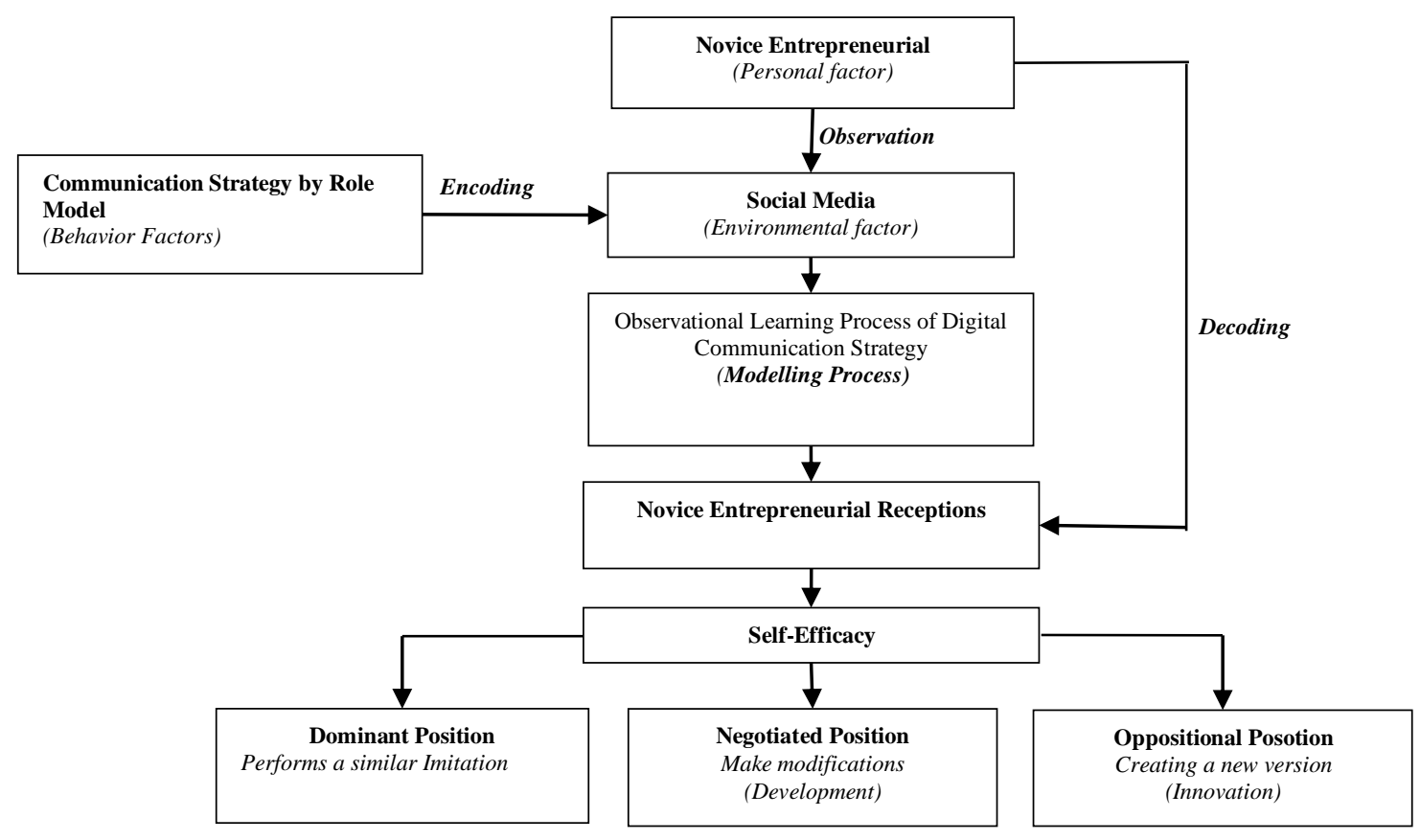

Figure 1. The Learning Process of Communication Strategies by Novice Entrepreneurs through Modeling in Social Media

In other words, in the process of learning social media communication strategies, in a position of acceptance of the opposition, novice entrepreneurs have self-efficacy in 
their knowledge and abilities. Therefore, in the position of opposition acceptance, novice entrepreneurs will rely on their knowledge and ability to make communication strategies according to their knowledge and abilities and get the results of innovations. The pattern of the whole process of learning communication strategies by novice entrepreneurs through modeling in social media is illustrated in the following figure 1.

\section{Implication}

The results of this study are expected to provide an important understanding of digital communication strategies for entrepreneurs who are just starting their business in building product identity and business reputation that have limited resources, especially knowledge and experience, by carrying out the learning process through observing te role models on social media to develop their business. By modeling communication strategies on social media by observing other businesses, business partners, and other content creators, novice entrepreneurs must be more selective in choosing the communication strategies needed by combining, comparing, and modifying the studied social media communication strategy. This is vital in making the decision of making similar imitation, developing strategies that have been observed, or creating new versions of strategies.

This research relies on a case study of novice entrepreneurs in the city of Surakarta. The empirical generalizations of this study are limited and are not the aim of this study. Therefore it must be generalizable. In accordance with the results of the study, further research are likely to test (1) the relationship between entrepreneurial relationships and their role models on social media, (2) test previous knowledge or relating to entrepreneurial relationships such as education, experiences that determine self-success in interpreting communication strategy tasks that are known on social media.

\section{Conclusion}

Regardless of where and how role models are observed by novice entrepreneurs in learning social media communication strategy, the results show that role modeling occurred based on the needs of start-up entrepreneurs. Micro, small, or medium enterprises' needs are based on the social media communication strategy tasks studied in Social media environments, such as Instagram, Website, and YouTube videos. In this study, novice entrepreneurs seek references related to the tasks of social media communication strategies, for example, on the strategies for disseminating and sharing information to customers, promotion and mobilization, listening to customers through customer service and dialogue, and taking advantage of influencer support.

Related to modeling on social media, how novice entrepreneurs accept social media communication strategies that have been studied can be interpreted correctly by novice entrepreneurs will greatly determine the success of their learning process. The results of social media communication strategy modeling, in the dominant acceptance position, will imitate similar to the modeled social media communication strategy. In the negotiated acceptance position, novice entrepreneurs only partially adopt and develop social media strategies according to their knowledge and abilities in the acceptance position. In negotiation, novice entrepreneurs have strong self-efficacy by their abilities and will create a new version of social media communication strategy.

The results also show that self-efficacy (Markowska \& Wiklund, 2020; Newman, Obschonka, Schwarz, Cohen, \& Nielsen, 2019) plays a very important role in the reception of novice entrepreneurs in modeling observed social media communication 
strategies that determine the decision of novice entrepreneurs to adopt by doing similar imitations, developing strategies that have been developed observed, or creating a new version of the strategy.

\section{References}

Bandura, A. (1977). Social Learning Theory. In Prentice-Hall. Inc. Englewood Cliffs, New Jersey: Prentice-Hall, Inc.

Bandura, A. (1986). Social foundations of thought and action: A social cognitive theory. Englewood Cliffs, NJ: Prentice-Hall.

Bandura, A. (2012). Social Cognitif Theory. Handbook of theories of social psychology. Volume 1 (E. Lange. P. A. M. V.; Kruglanski, A.W; \& Higgins, ed.). London: Sage Publications Ltd.

Basri, W. S., \& Siam, M. R. A. (2017). Maximizing the social media potential for small businesses and start-ups: A conceptual study. International Journal of Economic Perspectives, 11(2), 241-245.

Bosma, N., Hessels, J., Schutjens, V., Praag, M. Van, \& Verheul, I. (2012). Entrepreneurship and role models. Journal of Economic Psychology, 33(2), 410424. https://doi.org/10.1016/j.joep.2011.03.004

BPS. (2017a). Analisis Ketenagakerjaan Usaha Mikro dan Kecil (Employment analysis of micro and small enterprises). Sensus Ekonomi. Jakarta.

BPS. (2017b). Potensi UKM Provinsi Jawa Tengah. Retrieved from https://jateng.bps.go.id

Bresciani, S., \& Eppler, M. J. (2010). Brand new ventures? Insights on start-ups' branding practices. Journal of Product and Brand Management, 19(5), 356-366. https://doi.org/10.1108/10610421011068595

Chen, Z. F., Ji, Y. G., \& Men, L. R. (2017). Strategic Use of Social Media for Stakeholder Engagement in Startup Companies in China. International Journal of Strategic Communication, 11(3), 1-24. https://doi.org/10.1080/1553118X.2017.1298114

Fiet, J. O. (2001). The theoretical side of entrepreneurship theory. Journal of Business Venturing, 16(1), 1-24. Retrieved from http://www.sciencedirect.com/science/article/pii/S0883902699000415

Hall, S. (1973). Encoding, decoding. In: During S (ed.) The Cultural Studies Reader. London: Routledge.

Hoffmann, A., Junge, M., \& Malchow-Møller, N. (2015). Running in the family: parental role models in entrepreneurship. Small Business Economics, 44(1), 79104. https://doi.org/10.1007/s11187-014-9586-0

Kacperczyk, A. J. (2013). Social influence and entrepreneurship: The effect of university peers on entrepreneurial entry. Organization Science, 24(3), 664-683. https://doi.org/10.1287/orsc.1120.0773

Markowska, M., \& Wiklund, J. (2020). Entrepreneurial learning under uncertainty: exploring the role of self-efficacy and perceived complexity. Entrepreneurship and Regional Development, $00(00), \quad 1-23$. https://doi.org/10.1080/08985626.2020.1713222

Matthew B. Miles, A. Michael Huberman, J. S. (2014). Qualitative data analysis: a methods sourcebook (third edit). https://doi.org/10.16309/j.cnki.issn.10071776.2003.03.004

Men, L. R., \& Tsai, W. H. S. (2012). How companies cultivate relationships with 
publics on social network sites: Evidence from China and the United States. $\begin{array}{llll}\text { Public Relations } & \text { Review, }\end{array}$ https://doi.org/10.1016/j.pubrev.2011.10.006

Newman, A., Obschonka, M., Schwarz, S., Cohen, M., \& Nielsen, I. (2019). Entrepreneurial self-efficacy: A systematic review of the literature on its theoretical foundations, measurement, antecedents, and outcomes, and an agenda for future research. Journal of Vocational Behavior, 110(May 2018), 403-419. https://doi.org/10.1016/j.jvb.2018.05.012

Park, J. Y., Sung, C. S., \& Im, I. (2017). Does social media use influence entrepreneurial opportunity? A review of its moderating role. Sustainability (Switzerland), 9(9), 1-16. https://doi.org/10.3390/su9091593

Petkova, A. P., \& Rindova, V. P. (2008). How can New Ventures Build Reputation ? An Exploratory Study. Corporate Reputation Review, 11(4), 320-334. https://doi.org/10.1057/crr.2008.27

Saxton, G. D., \& Waters, R. D. (2014). What do Stakeholders Like on Facebook? Examining Public Reactions to Nonprofit Organizations' Informational, Promotional, and Community-Building Messages. Journal of Public Relations Research, 26, 280-299. https://doi.org/10.1080/1062726X.2014.908721

Shaw, A. (2017). Encoding and decoding affordances: Stuart Hall and interactive media technologies. Media, Culture and Society, 39(4), 592-602. https://doi.org/10.1177/0163443717692741

Tambunan, T. (2019). Recent evidence of the development of micro, small and medium enterprises in Indonesia. Journal of Global Entrepreneurship Research, 9(1), 115. https://doi.org/10.1186/s40497-018-0140-4

Turan, M., \& Kara, A. (2018). Online social media usage behavior of entrepreneurs in an emerging market: Reasons, expected benefits and intentions. Journal of Research in Marketing and Entrepreneurship. https://doi.org/10.1108/JRME-092016-0034

Wang, C. L., \& Chugh, H. (2014). Entrepreneurial learning: Past research and future challenges. International Journal of Management Reviews, 16(1), 24-61. https://doi.org/10.1111/ijmr.12007

Yin, R. K. (2018). Case study research and applications: Design and methods. In SAGE Publications, Inc (Sixth Edit). https://doi.org/10.1177/109634809702100108

Zozimo, R., Jack, S., \& Hamilton, E. (2017). Entrepreneurial learning from observing role models. Entrepreneurship and Regional Development, 1-23. https://doi.org/10.1080/08985626.2017.1376518 